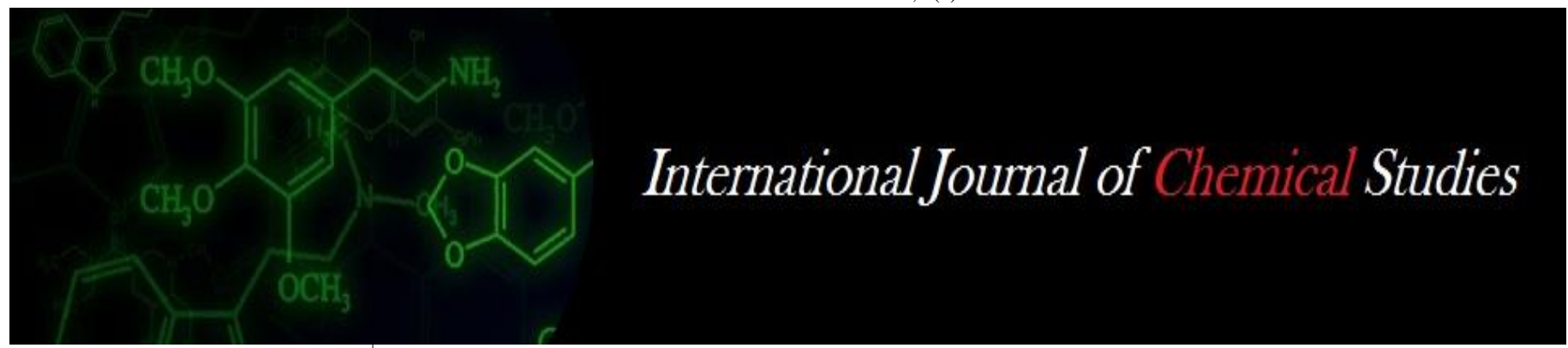

P-ISSN: 2349-8528

E-ISSN: 2321-4902

www.chemijournal.com

IJCS 2021; 9(1): 2357-2362

(C) 2021 IJCS

Received: 07-11-2020

Accepted: 18-12-2020

Neema Pawa

Research Scholar, Department of

Horticulture, College of

Agriculture, GB Pant University

of Agriculture and Technology,

Pantnagar, US Nagar,

Uttarakhand, India

Omveer Singh

Professor, Department of

Horticulture, College of

Agriculture, GB Pant University

of Agriculture and Technology,

Pantnagar, US Nagar,

Uttarakhand, India
Corresponding Author:

Neema Pawar

Research Scholar, Department of Horticulture, College of

Agriculture, GB Pant University of Agriculture and Technology,

Pantnagar, US Nagar,

Uttarakhand, India

\section{Efficacy of Aloe vera based composite edible coatings to maintain the post-harvest appearance of Ber fruits (Zizyphus mauritiana) cv. Umran}

\author{
Neema Pawar and Omveer Singh
}

DOI: $\underline{\text { https://doi.org/10.22271/chemi.2021.v9.i1ag.11578 }}$

\begin{abstract}
Umran is a most popular variety in India among other cultivars of Ber (Zizyphus mauritiana Lamk.) fruit. It provides nutritious fruit at very low cost even under marginal growing conditions but has short shelf life of 3-5 days. The research conducted to check the efficacy of Aloe vera gel based composite edible coating to maintain the post-harvest physical attributes of Ber fruits. After harvesting, the fruits were coated with Aloe vera gelincorporated with texture enhancer (calcium gluconate@ 1 and 2\%) and antioxidant (ascorbic acid @ 1 and 2\%) and stored at ambient storage condition sup to 15 days. Among all the treatments $75 \%$ Aloe vera gel incorporated with $1 \%$ ascorbic acid significantly reduces the physiological loss in weight $(8.89 \%)$, decay per cent $(10.08 \%)$, shrinkage of fruits $(5.03 \%)$ and retained Better fruit weight $(14.98 \mathrm{~g})$, diameter $(2.42 \mathrm{~cm})$ and firmness of fruits $\left(1.09 \mathrm{~kg} / \mathrm{cm}^{2}\right)$ up to 15 days. While the uncoated (control) ber fruits start losing their physical attributes after 5 days.
\end{abstract}

Keywords: Ediblecoatings, composite, PLW, shrinkage, firmness, decay, ambient storage

\section{Introduction}

Ber (Zizyphus mauritiana Lamk.) is one of the most important ancient, indigenous minor fruit crop in arid and semi-arid regions in India. It belongs to genus Zizyphus of the family Rhamnaceae and order Rhamnales. It is popularly called as "The king of arid zone" fruit. It can be in the reach of the poor people and hence known as poor man's fruit (Yamadagni, 1985; Shoba 2007) [21, 27]. Ber is popular because of its high economic returns, low cost of cultivation, wider adaptability and skill to face up to drought (Chadha and Pareek, 1983) ${ }^{[8]}$. Ber is grown in India traditionally from past where it's been in use for nearly 4000 years (Prakash, 1961) ${ }^{[20,27]}$. In India Rajasthan, Haryana, Uttar Pradesh, Gujarat, Madhya Pradesh, Bihar, Maharashtra, Andhra Pradesh and Tamil Nadu are the major ber growing states of the country. The area of ber in India is reported to be 52,000 hectare with the production of 639,000 MT (Anonymous, 2019-20) ${ }^{[1]}$. About 125 varieties of ber are available in India and few of those varieties are known for taste, size, better yields and amount of pulp. The major cultivated variety i.e, Umran, Kathapal and Gola are the most promising varieties of ber in North India (Azam-Ali, 2001) ${ }^{[2]}$. Chinese jujube highest in levels of polyphenol, tannin, glutathione, and ascorbic acid contents (Taraneh and Asna, 2012) ${ }^{[25]}$. Ber is widely used in folk medicines for treatment of allergies, constipation, insomnia, depression, chronic bronchitis, fever and enlargement of liver (Tanmay et al., 2011) ${ }^{[24]}$. The richness of the pulp of ber in nutritive compounds has been widely known and reported to contain of phytochemicals and minerals like amino acids, carbohydrates, ascorbic acid, flavonoids, phenolic acids, vitamins A and C, phosphorus, calcium, and iron (Yamadagni, 1985; Shoba, 2007) ${ }^{[21,27]}$.

Edible coating using natural bio materials is being explored as a safer alternative to make longer the shelf life of perishable food crops. Aloe vera gel has been identified as a novel coating agent with good anti-microbial properties (Ahmed et al., 2009) ${ }^{[30]}$. Aloe vera commonly referred to as a "medicinal plant", is known for its wide range of therapeutic properties. The most common species are Aloe barbadensis and Aloe arborescence. It is mentioned throughout the recorded history and has been given high ranking for an all-purpose herbal plant (Eshun and He, 2005) ${ }^{[9]}$. Jawadul et al. $(2014)^{[14]}$ observed that the Aloe vera gel inhibited the growth of both gram-positive and gram-negative bacteria. 
Ber is an underutilized fruit crop where the climate is semiarid and can be successfully cultivated in the marginal ecosystem of the subtropics and tropics (Pareek 2001) ${ }^{[8,19]}$. There is a great potentiality to enhance the shelf life of ber through use of different coating materials. But very fewer researches have been conducted on use of different coatings in ber. Therefore, this experiment has been proposed to know the effect of Aloe vera gel-based coatings on the shelflifeextensionand quality of ber cv. Umran.

\section{Materials and Methods \\ Plant material and experimental design}

Fruits of Ber (Zizyphus mauritiana Lamk.) cv. Umran were harvested at the commercial ripening stage from Horticulture Research Centre, Pattharchatta, Pantnagar. The experiment was laid down in two factorial completely randomized designs (FCRD) with three replications. Factors first includes 11 treatments i.e., concentration of base coating materialat 75 and $100 \%$ Aloe vera gel incorporated with functional ingredients (ascorbic acid and calcium gluconate). Factor two includes different storage intervals $\left(0,5,10\right.$ and $15^{\text {th }}$ days $)$ at ambient room temperature.

\section{Preparation of Aloe vera gel coating}

Fresh Aloe vera leaves collected from Medicinal Research and Development Centrte, Pantnagar and brought to Post harvest laboratory of department of Horticulture. Then they were washed to remove adherent dirt material. Aloe vera gel preparation was undertaken according to Ramachandra and Rao (2008) ${ }^{[31]}$ who suggested that Aloe vera leaves must be processed within 2 hours of harvesting to prevent oxidation of the gel due to their exposure to air. Aloe vera gel matrix was separated from the cortex of leaves using sharp knife and then the colorless hydro parenchyma was grinded in a blender and strained through sieve to remove thick particles.

The Aloe gel was pasteurized at $85{ }^{\circ} \mathrm{C}$ for 1 minute. Before pasteurization, the $\mathrm{pH}$ of the gel was adjusted to 3.0 by the addition of citric acid to stabilize and prevent browning (Maughan, 1984) ${ }^{[12]}$. After pasteurization, the gel was quickly cooled to $5{ }^{\circ} \mathrm{C}$ or below. Finally, the Aloe vera gel was filled into pre-sterilized, opaque glass bottles for storage in a chiller at $5{ }^{\circ} \mathrm{C}$ and $75-80 \%$ relative humidity. Accordingly, a coating of Aloe vera gel was made in $75 \%$ and $100 \%$ with water. Thereafter, 1 and $2 \%$ of ascorbic acid (as an antioxidant) and 1 and $2 \%$ calcium gluconate (as a texture enhancer)was added to gel according to treatment combination and heated the solution at required temperature for pasteurization. Fruits were treated with different coating (11) treatments for 2 minutes and then allowed to dry for 2 hours at room temperature. The analysis of the fruits was done at every 5 days intervals. 60 fruits per treatment were dipped in these coating solutions for two minutes in three replications. Ten fruits in each replication were undisturbed for evaluation of PLW, shrinkage percentage, decay percentage, fruit weight, fruit diameter and firmness.

\section{Physical quality attributes}

The weight of ber fruits was measured on electronic balance and Vernier calipers. The physiological loss in weight (PLW) of the fruits was calculated by the difference between initial and final weight of fruit at each of storage interval and expressed in percentage. The firmness of fruits was measured by using Fruit pressure tester i.e., penetrometer (Model No. BGS-25, Make-Biogen). The length and breadth of fruits were measured by digital vernier calipers during the storage period as an index for shrinkage. Decay percentage of coated and uncoated fruit was calculated as the number of decayed fruits divided by initial number of all fruit multiplied by 100 at subsequent intervals.

\section{Statistical analysis}

Data for the physical parameters were subjected to analysis of two factorial completely randomized designs as given by Snedecor and Cochran (1987) ${ }^{[29]}$. Results were compared for the treatments and storage time was significant at $P<0.05$. The data were presented through graphs.

\section{Results and Discussion \\ Fruit weight}

Maximum fruit weight retention $(14.98 \mathrm{~g}$ ) found in T2 (Aloe vera gel @ 75\% + ascorbic acid 1\%) which is statistically at par with the T1 (AG@ @5\%) and T3 (AG @ 75\% + AA 2\%) i.e., $14.87 \mathrm{~g}$ and $14.69 \mathrm{~g}$ respectively, whereas control (T11) uncoated fruits showed minimum $(8.92 \mathrm{~g}$ ) fruit weight (Fig.1). Fruit weight decreased gradually irrespective of the treatments as the storage period progressed. Application of Aloe vera gel composite coating retarded the weight loss of ber fruits during storage as compared to the control. Higher fruit weight was retained in fruits due to less moisture loss which lead to the reduction in loss of turgidity and thus maintaining better fruit weight compared to control fruits which lost more moisture (Baraiya et al., 2014) ${ }^{[5]}$. Ber fruits coated with ascorbic acid retained the higher weight during the storage (Singh et al., 2018).

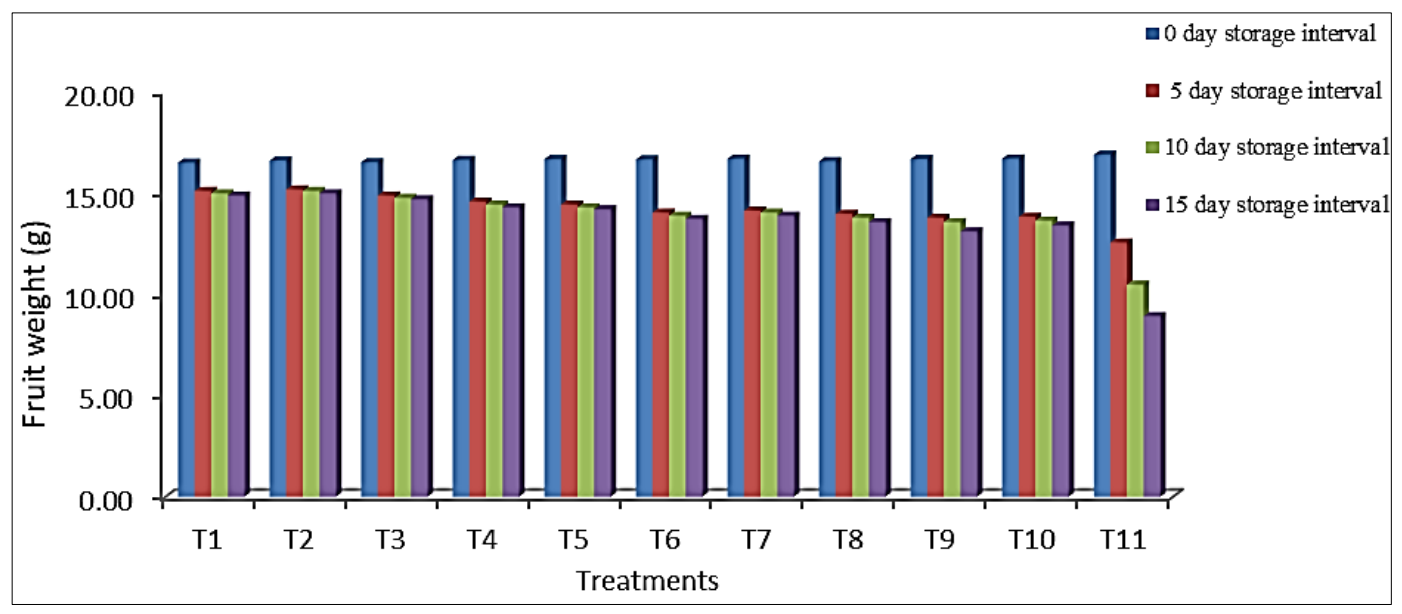

Fig 1: Effect of composite edible coating on fruit weight $(\mathrm{g})$ of Ber cv. Umran. Data are the mean \pm SE. For each treatments and storage intervals bars with different color are significantly different $(p<0.05)$. 


\section{Fruit diameter}

Fruit diameter decline gradually irrespective of the treatment as the storage period progressed. The losses in diameter of ber fruit were due to loss of moisture which leads to loss in fruit size (Fig.2). The loss in fruit diameter is maximum $(1.08 \mathrm{~cm}$ from $2.77 \mathrm{~cm}$ initially) in case of control (T11) samples whereas minimum loss in fruit diameter was found in $\mathrm{T}_{1}(2.42$ $\mathrm{cm})$ followed by $\mathrm{T} 2(2.39 \mathrm{~cm})$. Composite edible coating formed a semi permeable film that regulated gaseous exchange and reduced the transpiration rate, which is determined by the gradient of the water vapour pressure between the fruit and the surrounding air (Bautista-Banos et al., 2006). Similar results were reported by Singh et al. (2017) $[15-17,22,23,30]$ in peach fruits where they studied the influence of different postharvest calcium treatments and storage conditions on quality of peach cv. Shan-e-Punjab.

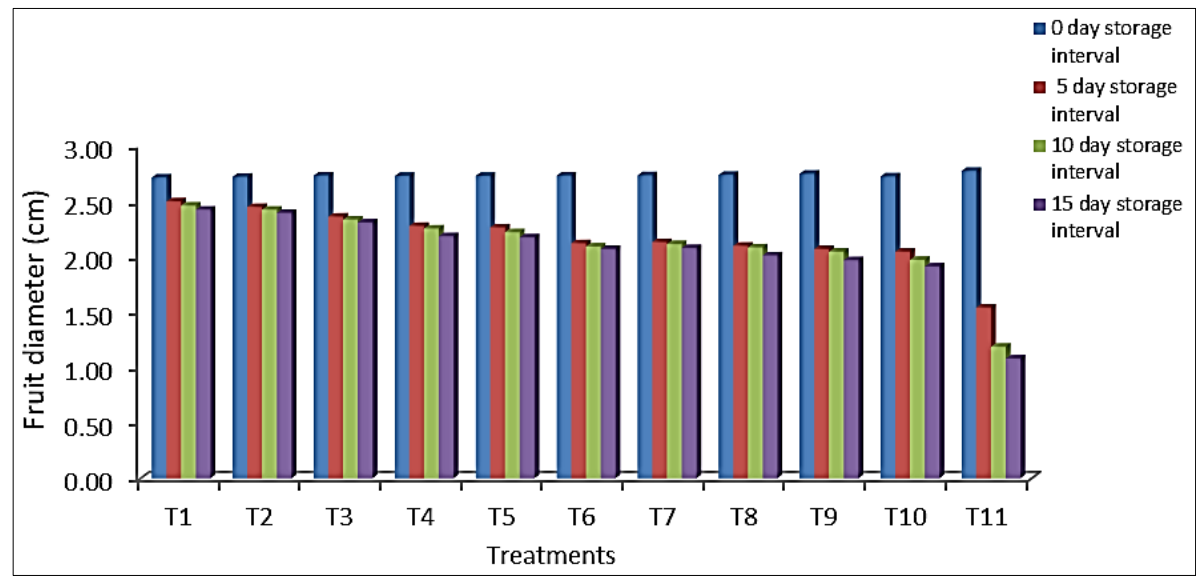

Fig 2: Effect of composite edible coating on fruit diameter $(\mathrm{cm})$ of Ber $\mathrm{cv}$. Umran. Data are the mean $\pm \mathrm{SE}$

\section{Fruit firmness $(\mathrm{kg} / \mathrm{cm} 2)$}

It was noticed that firmness reduced as ripening progressed (Fig.3). However, the rate of loss in firmness was significantly higher in untreated fruits as compared to treated fruits measured on 15th day of storage. At the time of ambient storage conditions the highest $(1.09 \mathrm{~kg} / \mathrm{cm} 2)$ firmness was recorded in T2 (Aloe vera gel @ 75\% + AA 1\%) which is statistically at par with the T1 (AG@ @ $75 \%$ + AA $2 \%$ ) i.e., 1.07 and $1.02 \mathrm{~kg} / \mathrm{cm} 2$ respectively, while the minimum fruit firmness $(0.89 \mathrm{~kg} / \mathrm{cm} 2)$ was observed in T11 (control) followed by T10 (Aloe vera @ 100\% + ascorbic acid $2 \%+$ calcium glugonate $2 \%$ )i.e., $0.817 \mathrm{~kg} / \mathrm{cm} 2$ at 15 th days storage intervals. These results are incloseconformity with the findings of Singh et al. (2018) [15-17, 22, 23, 30] who illustrated that guava fruits treated with $20 \%$ Aloe vera was effective in extending the shelf life as it retained greater firmness $(2.59 \mathrm{~kg} \mathrm{~cm}-2)$ in winter season guava fruits. During ripening, parenchyma cell walls are extensively modified, altering their mechanical properties, and cell adhesion is significantly reduced as a result of middle lamella dissolution. Cell wall and middle lamella modifications leading to fruit softening result from the action of cell wall modifying enzymes (e.g. polygalacturonase, pectin methylesterase, pectate lyase, b-galactosidase, cellulase), generally encoded by ripening-related genes (Brummell and Harpster, 2001; Goulao and Oliveira, 2008; Mercado et al., 2011) ${ }^{[7,10,18] .}$ Calcium compounds are responsible for the maintaining the firmness of fruits by delaying the fruit maturity and increasing the thickening of middle lamella of cells owing to increased deposition of calcium pectate (Gupta et al., 1984) ${ }^{[11]}$.

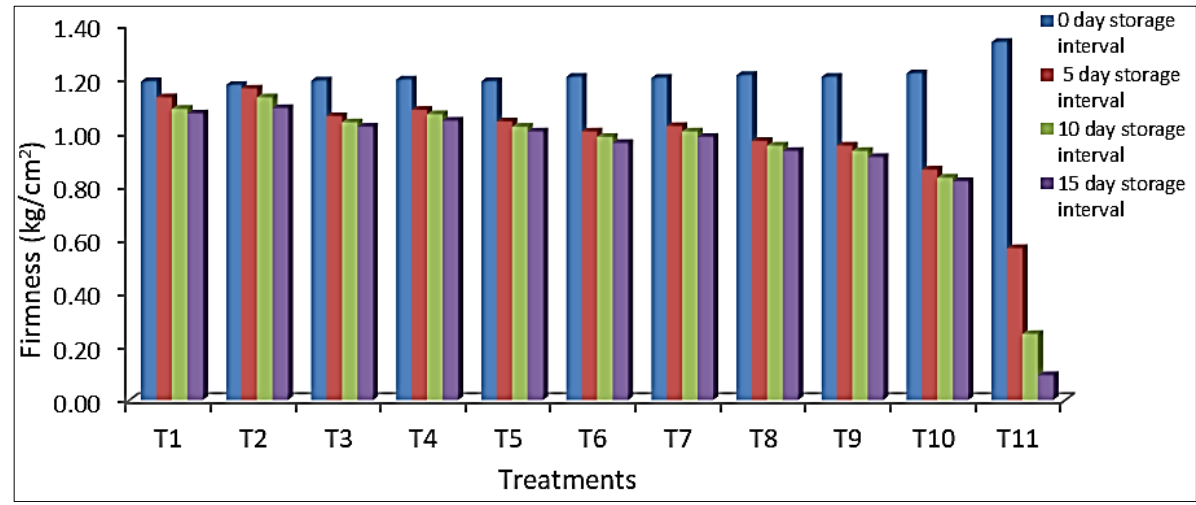

Fig 3: Effect of composite edible coating on fruit firmness $\left(\mathrm{kg} / \mathrm{cm}^{2}\right)$ of Ber cv. Umran. Data are the mean $\pm \mathrm{SE}$

\section{Physiological loss in weight (PLW)}

Figure 4 represents the physiological loss in weight of treated and untreated ber fruits. Clearly it can be observed that the highest loss in physiological weight $(23.74 \%)$ was found in T11uncoated fruits (control)at 5th day which was increased to $40.94 \%$ at 15 th day of storage period. Treatment second (Aloe vera gel @ 75\% + ascorbic acid 1\%) was found most performing as it showed minimum (8.89\%) loss in physiological weight of Ber fruits which is statistically at par with the T1 (AG @ 75\%) i.e., 9.55\% on 15th day storage period at room temperature.

The weight loss of the fruit is mainly associated with respiration and moisture evaporation through their skin. The rate at which water is lost depends on the water pressure gradient between the fruit tissue and the surrounding atmosphere, and the storage temperature (Hernandez et al., 
2008) ${ }^{[6,13]}$. The basic mechanism of weight loss from fresh fruit and vegetables is by vapour pressure at different locations (Yamanand et al., 2002) ${ }^{[28]}$, although respiration also causes a weight reduction. The reduction in weight loss was probably due to the effects of these coatings as a semi permeable barrier against oxygen, carbon dioxide, moisture and solute movement, thereby reducing respiration, water loss and oxidation reaction rates (Baldwin et al., 1999) ${ }^{[3,4]}$. The physiological loss of weight of ber fruits were recorded in this present experiment. Similar observation was reported by Kaur et al. $(2014)^{[16]}$ in guava fruits during the storage period.

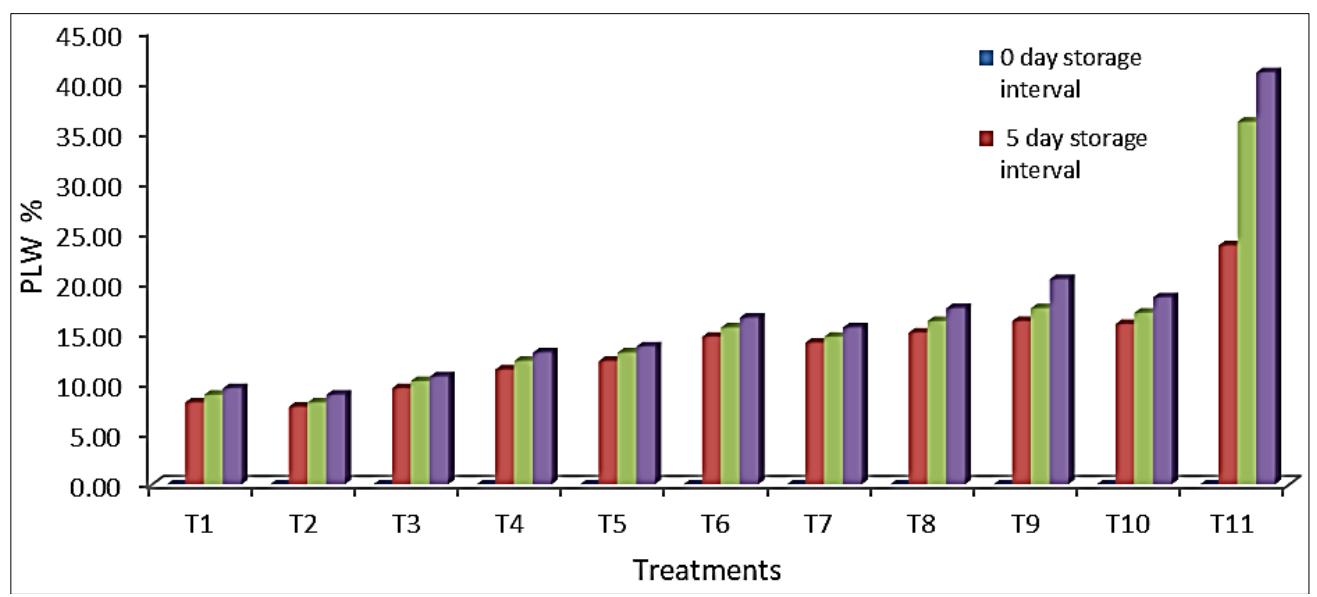

Fig 4: Effect of composite edible coating on PLW (\%) of Ber cv. Umran. Data are the mean \pm SE

\section{Shrinkage (\%)}

Figure 5 shows the shrinkage percentage of the coated and uncoated ber fruit samples during ambient storage conditions. It was found that there was a slow decline in the shrinkage percentage in coated fruits as compared to uncoated fruits. It can be clearly observed that the shrinkage percentage is maximum in case of control $(58.40 \%)$ fruits while minimum shrinkage percentage $(5.03 \%)$ was noticed in T4 (AG @ 75\%
+ AA $1 \%+$ CG $2 \%$ ) followed by $6.71 \%$ in T3 (AG @ $75 \%+$ AA $2 \%$ ) on 15 th day storage condition. It might be due to the anti-senescent action of coatings which had an inhibitory effect on ethylene biosynthesis and retard the activity of enzymes responsible for ripening. Cell degradation was prevented which in turn facilitated reduced moisture loss and lesser respiratory gas exchange, hence delay in senescence and lower the shrinkage percentage (Mani et al., 2017) ${ }^{[17]}$.

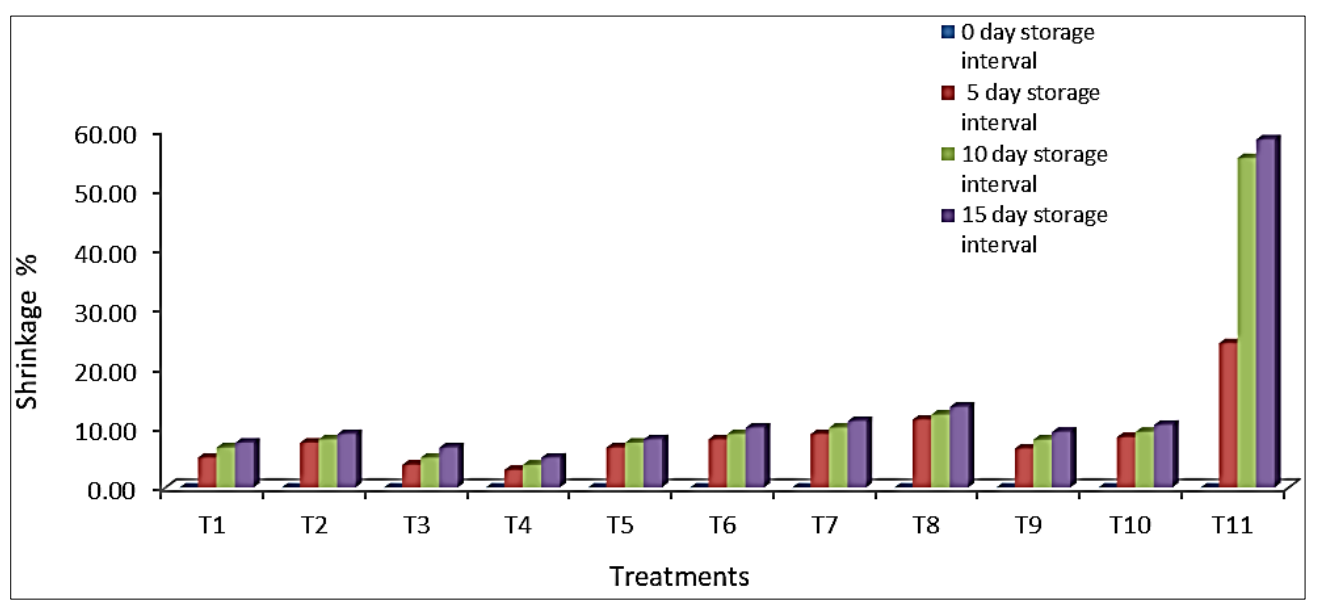

Fig 5: Effect of composite edible coating on fruit shrinkage (\%) of Ber cv. Umran. Data are the mean \pm SE

\section{Decay $(\%)$}

Initially there was no visible sign of decay in coated fruits up to 5th days of the storage period (Fig. 6). The results regarding to the effect of Aloe vera gel composite coatings on fruit decay per cent varied significantly during storage period. Aloe vera gel composite coating treated fruits started decay after 10th days of storage period with minimum fruit decay per cent $(10.08 \%)$ was noticed in $75 \%$ Aloe vera gel incorporated with $1 \%$ ascorbic acid coating (T2) followed by $12.67 \%$ in $\mathrm{T} 1$ (75\% Aloe veragel) and maximum decay percentage $(87.50 \%)$ was found in controlleduncoated samples. Decay per cent in Aloe vera gel composite coating treatments was less because Aloe vera gel not only reduced the rate of respiration and ripening process but it can significantly inhibit the growth of bacteria, fungi and molds which cause rotting in fruits during storage. Composite edible coating induces a strong defense system in coated fruits i.e. antifungal, antimicrobial and antibacterial properties. Similar results was observed by Jawandha et al. $(2014)^{[15,16]}$ who opined that percent spoilage of Baramasi lemon fruits was increased with the extension in storage period due to the weakening of the defence system against fungal attack. The present results are in corroboration with earlier work of Mani et al. $(2018)^{[17]}$ in ber. 


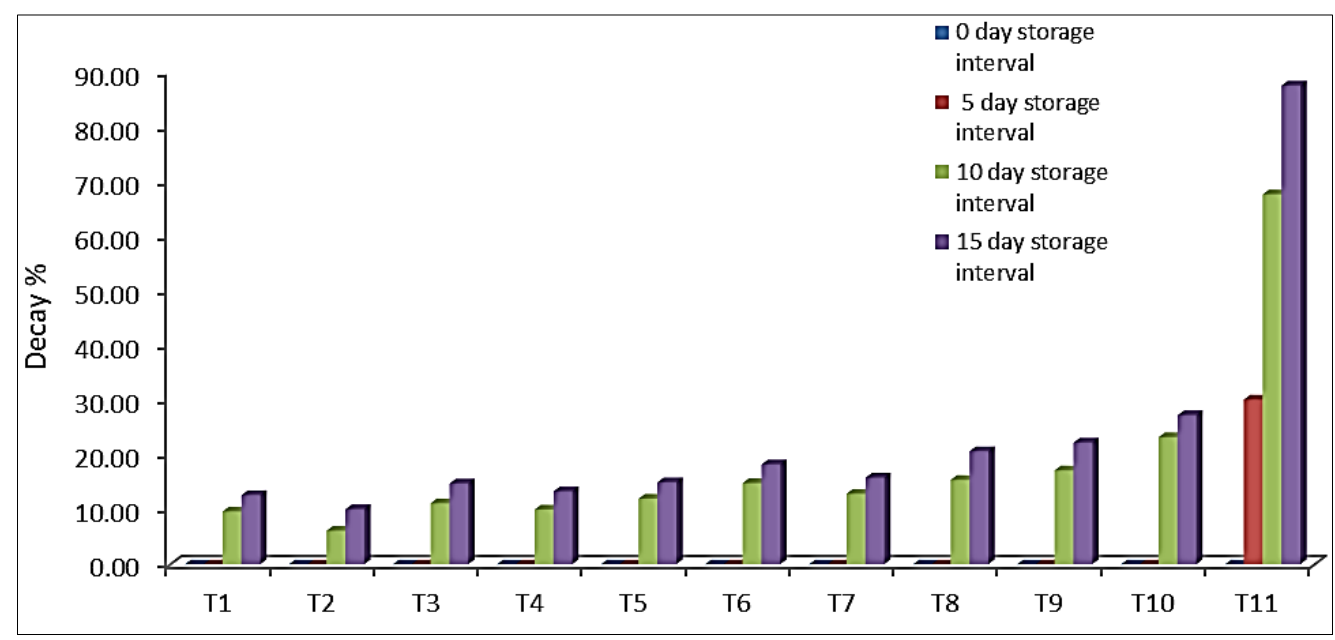

Fig 6: Effect of composite edible coating on fruit decay (\%) of Ber cv. Umran. Data are the mean \pm SE

\section{Conclusion}

Conclusively, results indicated that the application of Aloe vera gel composite edible coatings prolongs the shelf life and maintain the appearance of ber fruits up to 15 days. The study particularly suggested that Aloe vera gel composite coating incorporated with $1 \%$ ascorbic acid as an anti-oxidant showed positive effects on ber fruit in terms of their weight, diameter, firmness, per cent physiological loss in weight, shrinkage and decay percentagea after harvesting and during the storage period. So, it can be said that Aloe vera gel extended the shelf life of ber fruits but when combined with Vitamin $\mathrm{C}$ as anatural antioxidant and showed a greater possibility to preserve the appearance of ber fruit.

\section{References}

1. Anonymous 2019-20.

http://nhb.gov.in/Statistics/Area/Production/Statistics.

Area and production of horticulture crops for 2019-20

2. AzamAli S, Bonkoungou E, Bowe C, DeKock C, Godara A, Williams JT. Fruits for the future (revised edition) Ber and other jujubes. International Centre for Underutilized Crops, University of Southampton, Southampton, SO17 1BJ, UK 2001.

3. Baldwin E. Surface treatments and edible coating in food preservation. In: Rahm MS (2007). Handbook of food preservation. CRC, ISBN 9781574446067 2007, P496 of 1088.

4. Baldwin EA, Burns JK, Kazokas W, Brecht JK, Hagenmaier RD, Bender RJ, Peris E. Effect of two edible coatings with different permeability characteristics on mango (Mangifera indica L.) ripening during storage. Postharvest Biol Technol 1999;17:215-226.

5. Baraiya NS, Rao TVR, Thakkar VR. Enhancement of storability and quality maintenance of carambola (Averrhoa carambola L.) fruit by using composite edible coating. Fruits 2014;69(3):195-205.

6. Bautista-Baños S, Hernandez-Lauzardo AN, VelazquezDel Valle MG, Hernández-López M, Barka EA, Bosquez-Molina E, Wilson CL. Chitosan as a potential natural compound to control pre and postharvest diseases of horticultural commodities. Crop Protection 2006;25(2):108-118.

7. Brummell DA, Harpster MH. Cell wall metabolism in fruit softening and quality and its manipulation in transgenic plants. Plant Molecular Biology 2001;47:311340.
8. Chadha KL, Pareek OP. Floral Biology of Ber. In: Advances in Horticulture, Vol. I. Malhotra Publishing House, New Delhi 1993, P412-416.

9. Eshun K, He Q. Aloe vera: a valuable ingredient for the food, pharmaceutical and cosmetic Industriessa review. Crit. ReV. Food Sci. Nutr 2005;44:91-96.

10. Goulao LF, Oliveira CM. Cell wall modification during fruit ripening: when a fruit is not the fruit. Trends in Food Science \& Technology 2008;19:4-25.

11. Gupta OP, Kainsa RL, Chauhan KS, Dhawan SS. Postharvest studies in ber fruits (Ziziphus mauritiana Lamk.) IV. Comparison of sugar and gur for the preparation of candies. Journal of Research 1981;1:369-392.

12. Maughan RG. Method to increase color fastness of stabilized aloe vera. US Patent 1984;4:465, 629.

13. Hernandez-Munoz EA, Valle VD, Velez D, Gavara R. Effect of chitosan coating with postharvest calcium treatment on strawberry (Fragaria $x$ ananassa) quality during refrigerated storage. Journal of Food Chemistry 2008;110:428-435.

14. Jawadul M, Fatema Brishti H, Hoque MM. Aloe vera gel as a Novel Edible Coating for Fresh Fruits: A Review. American Journal of Food Science and Technology 2014;2(3):93-97.

15. Jawandha SK, Singh H, Arora A, Singh J. Effect of modified atmosphere packaging on storage of Baramasi lemon (Citrus limon (L.) Burm). International Journal of Agriculture, Environment and Biotechnology 2014;7(3):635-638.

16. Kaur S, Jawandha SK, Singh J. Response of baramasi lemon to various post-harvest treatments, International Journal of Agriculture, Environment and Biotechnology 2014;7(4):895-902.

17. Mani A, Jain N, Singh AK, Sinha M. Effects of Aloe vera edible coating on quality and postharvest physiology of Ber (Zizyphus mauritiana Lamk.) under ambient storage conditions. International Journal of Pure Applied Biosciences 2017;5(6):43-53.

18. Mercado JA, Pliego-Alfaro F, Quesada MA. Fruit shelf life and potential for its genetic improvement. In: Jenks MA, Bebeli PJ. eds. Breeding for fruit quality. Oxford: John Wiley \& Sons 2011, P81-104.

19. Pareek OP. Ber. International Centre for Underutilized Crops, Southampton, UK 132001.

20. Prakash O. Food and drinks in ancient India. Ph.D. Thesis, Delhi University, Delhi 1961. 
21. Shoba D, Bharati P. Value addition to Ber (Zyziphus mauritiana Lamk.) through preparation of pickle. Journal of Agricultural Sciences 2007;20(2):353-355.

22. Singh M, Jasrotia A, Bakshi P, Wali VK, Kumar R, Kour $\mathrm{K}$. Effect of various storage conditions and calcium treatments on physico-chemical properties of peach (Prunus persica) cv. Shan-e-Punjab. Indian Journal of Agricultural Sciences 2017;87(6):796-800.

23. Singh N, Misra KK, Dongariyal A, Rani A, Nirgude V. Response of different coating material on post-harvest life and quality of guava (Psidium guajava L.). International Journal of Chemical Studies 2018;6(2):2635-2639.

24. Tanmay KK, Shweta W, Prerna N, Awasthi OP, Charanjit K. Nutraceutical composition of Zizyphus mauritiana Lamk (Indian ber): effect of enzyme-assisted processing. International Journal of Food Sciences and Nutrition 2011;62(3):276-279.

25. Taraneh E, Asna U. Phytochemical Profile and antioxidant potential of different tissues of Zizyphus jujube Mill. International Journal of Food Nutrition and Safety 2012;1(3):144-157.

26. Tomas SA, Bosquez-Molina E, Stolik S, Sánchez F. Effect of mesquite gum-candelilla wax based edible coating on the quality of guava fruit (Psidium guajava L.). J Phys. IV France 2005;125:889-892.

27. Yamadagni R. Ber in: Fruits of India, Tropical and subtropical, Naya Prakash. Calcutta, India 1985.

28. Yamanand O, Bayoindirli L. Effects of an edible coating and cold storage on shelf-life and quality of cherries. Lebnsm. Wiss. Und. Technol 2002;35:46-150.

29. Snedecor GW, Cochran WG. Statistical Methods. Oxford and IBH Publishing Co. 66, Janpath, New Delhi-1 1987.

30. Ahmed MJ, Singh Z, Khan AS. Postharvest aloe vera gelcoating modulates fruit ripening and quality of 'arctic snow' nectarine kept in ambient and cold storage. International Journal of Food Science and Technology 2009;44:1024-1033.

31. Ramachandra CT, Rao PS. Processing of Aloe vera leaf gel: A review. American Journal of Agricultural and Biological Sciences 2008;3:502-510. 